\title{
The Emergence of the Concept of Unjust Enrichment in New Zealand, Its Relationship to the Remedial Constructive Trust and the Development of the Status of Joint Ventures in Equity
}

\author{
Sue Tappenden \\ School of law, University of Waikato, Private Bag 3105 Hamilton, New Zealand \\ Tel: 64-7-838-4466 E-mail: suetapp@waikato.ac.nz
}

\begin{abstract}
From the 1970s onward there have been numerous attempts to persuade the courts of New Zealand that unjust enrichment might be an acceptable basis for imposing equitable remedies. The foundation for this proposition rests upon the supposed existence of a broad principle that the imposition of a constructive trust is justified in any circumstances where it would be against equity or good conscience to allow the retention of property by one who has an ostensible legal title. So the unjust enrichment, once established, becomes the cause of action and the constructive trust follows as an equitable remedy of a proprietary nature which is available to prevent the unjust enrichment. This has important ramifications for the development of the law pertaining to restitution in this country. This paper will show that the acceptance of the remedial constructive trust is linked to the development of a law of restitution founded upon the principle of unjust enrichment. It will also be shown that, while the roots of the conceptual distinction between law and equity remain intact, in many courts the practical ramifications of that distinction are being eroded, particularly in commercial cases.
\end{abstract}

Keywords: Restitution, Constructive, Trust, Unjust, Enrichment, Equitable, Remedial, Commercial

\section{Introduction}

In England, in Hussey v Palmer (1972) 3 All ER 744, Lord Denning's proposal that a "new model" constructive trust may be imposed "whenever justice and good conscience require it" was overturned at the first opportunity by the House of Lords. In 1975 the New Zealand court declared, in Carly v Farrelly (1975) NZLR 356, that a general concept of "unjust enrichment" aggregating various heads of liability in equity did not form part of the law of England or New Zealand. However in some New Zealand judgments the remedial constructive trust has been adopted by which the court can enable an aggrieved party to obtain restitution.

In the New Zealand case of Carly v Farrelly counsel relied heavily on Lord Denning's stance and proposed that unjust enrichment is one of the elements that should rightly be taken into account in deciding whether the facts of a particular case were such as to support the inference of a constructive trust in favour of the plaintiff. This is a very liberal approach founded on large principles of equity in its basic sense without reference to the established rules of the Court of Chancery. Lord Denning's approach to equity was extremely liberal to the extent that he blurred the distinction between resulting and constructive trusts saying, "By whatever name it is described it is a trust imposed by law whenever justice or good conscience require it......It is an equitable remedy by which the court can enable an aggrieved party to obtain restitution". This was not a novel approach for Lord Denning. In 1948 in the English High Court Denning J said in Nelson v Larholt: (1948) 1 KB 339. "It is no longer appropriate, however, to draw a distinction between law and equity........Remedies now depend on the substance of the right, not whether they can be fitted into a particular framework. The right here is not peculiar to equity of contract or tort, but falls naturally within the important category of cases where the court orders restitution, if the justice of the case so requires".

The House of Lords, in subsequent cases did much to reduce the force of Lord Denning's words. In New Zealand we have embraced the notion of fusion between law and equity more readily than in England or Australia and the courts are more likely to be ready to find a remedial constructive trust based on unjust enrichment in order to give a remedy when principles of justice and good conscience require it. The remedial constructive trust is a very attractive device. Lord Browne-Wilkinson has hinted that the way forward for English law may involve the recognition of remedial constructive trusts and in the Westdeutsche case (Westdeutsche Landesbank Girozontrale v Islington Borough Council (1996) AC 669) he went so far as to explain the difference between the institutional and remedial constructive trusts. The former arises as at the date of the circumstances that give rise to it. The court merely acknowledges that the constructive trust has come into existence. On the other hand the latter is a judicial remedy which gives rise to an equitable obligation. It is at the discretion of the court and if the remedial constructive trust acts to the prejudice of 
third parties, this also is at the discretion of the courts. The main difference is that in the circumstances of the institutional constructive trust the proprietary interest exists before the plaintiff comes to court and the court just gives effect to a trust which arose out of specific circumstances. However, the remedial constructive trust gives rise to a previously non-existent proprietary interest at the discretion of the court to reverse some injustice, which is best described as an unjust enrichment.

\section{Fiduciary Duties in Commercial Relationships}

It is a big step for a court to assume the discretion to create an interest in property in favour of one who is not the legal owner as a remedy. Having taken such a step in assuming such a powerful discretion the court might also be willing to abandon the strict boundaries that have traditionally existed between different causes of action and be ready to accept a broader based foundation for a cause of action in unjust enrichment. In New Zealand the conceptual distinctions between law and equity are being eroded. This erosion of boundaries between law and equity has allowed the court to find that fiduciary relationships exist in commercial joint ventures where the parties were bound by contract, resulting in the award of an equitable remedy. In two recent cases the Supreme Court of New Zealand considered the links between commercial relationships and fiduciary duties. Even in cases where the parties have chosen to use an incorporated company as a vehicle for the joint venture, when it cannot be said that their relationship is wholly fiduciary, there may still be aspects of the relationship that engender fiduciary obligations. In Paper Reclaim Ltd v Aotearoa International Ltd (2007) NZSC 26 it was said that the "characterisation of a commercial arrangement as a joint venture can be unhelpful as a guide to whether the parties owe each other fiduciary obligations". In Maruha Corporation $v$ Amaltal Corporation Ltd (2007) NZSC 40, it was held that even in a commercial relationship of a generally non-fiduciary kind, there may be aspects leading to fiduciary obligations; ACL owed M fiduciary duty with regards to accounting and taxation functions undertaken and $\mathrm{M}$ was entitled to recover losses that resulted from the breach of duty.

In the earlier case of Dickie v Torbay Pharmacy (1986) (1995) 3 NZLR 429, the remedial constructive trust was applied after a fiduciary relationship was found to exist between potential joint venturers and the breach of the fiduciary duty occasioned the proprietary remedy. Hammond $\mathrm{J}$ considered the nature of a constructive trust and concluded that "functionally constructive trusts can, and do, serve a variety of purposes". He came to the conclusion that abstract theory should give way to the circumstances of a given case, the nature of the wrong and whether proprietary relief is appropriate. This approach gives rise to less criticism than cases where there is no fiduciary relationship and instead of a breach of fiduciary duty the only basis for the constructive trust is unjust enrichment.

\subsection{The Availability of Equitable Remedies}

Equity affords the judge the opportunity to protect property by way of a constructive trust and force the disgorgement of money to the party who has been wrongly denied it. In New Zealand it makes no difference whether the parties were engaged in a commercial enterprise which would normally have been governed by a contractual relationship, the equitable remedy is available. This is particularly evident in case involving joint ventures. In a recent example the Supreme Court heard the appeal from the Court of Appeal in the case of Chirnside v Fay (2006) NZSC 68. It was accepted by all members of the court (albeit for slightly different reasons) that parties to a joint venture owe each other fiduciary duties. The duty in question here was that of loyalty. The duty arose when Mr Chirnside participated with $\mathrm{Mr}$ Fay in plans for a business venture. It was agreed in the High Court, the Court of Appeal and the Supreme Court that the two men had embarked upon the venture by sharing an opportunity which each of them had identified independently, by doing calculations as to the feasibility of the project, by working on plans with architects and by negotiating for the purchase of a building site. The parties had also worked together to encourage a retailer to give a commitment that it would become a tenant on the site. This mutual participation created a duty of loyalty.

In excluding Mr Fay from the venture with Harvey Norman in the development of the site in Dunedin, Mr Chirnside breached the duty he owed Mr Fay. Whereas the High Court and the Court of Appeal referred to an award of damages to compensate Mr Fay for his loss, the Supreme Court declared that an account of profits was the most appropriate remedy. It was said by Elias J (at paragraph 17) that damages should be measured by what the plaintiff has lost whereas an account of profits would measure what the defendant had gained. In this case the account of profits would entitle Mr Fay to half the profit made by the venture. There was some disagreement between Elias J and the other members of the Court over an award to Mr Chirnside for his expertise in negotiating the deal. But this does not detract from the decided principle that the breach of his fiduciary loyalty had caused Mr Chirnside to disgorge half of his profit to Mr Fay. The award was calculated on the value of the completed project, even though when Mr Fay had been excluded the value of the site was much less. The profits were unauthorised and so could not be retained by the defaulting fiduciary. Because this is equitable relief the fiduciary needs not to have acted in bad faith or to have consciously done wrong and no loss needs to have resulted to the plaintiff.

In the Chirnside case it was shown that there had been a breach of fiduciary duty and the duty existed because of the parties' joint activities towards a common goal. The appropriate constructive trust in this case would have been an institutional constructive trust, rather than a remedial one, since the constructive trust would have arisen over the 
property at the time of the breach, not when the court declared it to have come into being. The obligations between the parties were quite distinct from any contractual obligations that may have bound Mr Chirnside and Mr Fay. It was not necessary to show that their relationship was akin to a partnership, and to find a fiduciary relationship through that route There was no need to find any kind of unevenness between them in their business experience or capabilities, so it was not necessary to explore whether one party was vulnerable to the other in any way. This is in contrast to the earlier case of Auag Resources Ltd v Waihi MinesLtd (1994) 3 NZLR 571 which was heard in the High Court in Auckland in 1994 by Barker J. The judgment was based on a detailed consideration of whether or not the joint venture agreement was a partnership agreement. Barker J cited many authorities, both academic and judicial, to support his proposition that if there is no fiduciary duty imposed by status, such as partnership, then some other factual basis for the fiduciary duty must be found, such as vulnerability of the complainant. After Chirnside this would appear to be the wrong approach. While many arms-length commercial transactions may not give rise to fiduciary obligations, the fact that the basis for the transaction is commercial does not preclude a fiduciary duty from arising.

\subsection{Differences and Common Origins}

In this area New Zealand is developing its law in a different direction to that of Australia, despite the fact that we rely on many of the same accepted authorities. The authorities relied on in both jurisdictions appear to have a common origin in a case from the US. In 1928 the Court of Appeals in New York decided a case in which the parties were engaged in a joint venture, the main object of which was to lease the Bristol Hotel on Fifth Avenue for 20 years from 1902, and convert it for use as offices and shops. Towards the end of the lease one of the parties was offered the chance to renew the lease on the hotel site in addition to neighbouring property with the object of destroying all the existing buildings and to build one new building to occupy the entire site. The rent would be $\$ 350,000$ to $\$ 475,000$ per annum as opposed to the $\$ 55,000$ paid for the Bristol site. The case was Meinhard v Salmon (1928) 249 N.Y. 458. The original 20 year lease had had four months to run when Salmon was approached by Gerry, who owned the entire tract of land on Fifth Avenue and Forty-Second Street. The new lease had a potential duration of 80 years, so the difference in the value between the old and the new was considerable. Although Gerry approached Salmon only there was no question of any fraud on his part because he was unaware of the connection between Salmon and Meinhard. Salmon's company, Midpoint Realty Company, and Gerry agreed the terms of the new lease in January 1922 and a month later Meinhard found out about it and claimed an interest in the new venture.

The case was decided by a narrow majority of 4 to 3 . The majority judgment was handed down by Cardozo Ch.J., Pound Lehman and Crane JJ concurring. At the outset Cardozo described the parties as "co adventurers, subject to fiduciary duties akin to those of Partners". He said that: "Joint adventurers, like copartners, owe to one another, while the enterprise continues, the duty of the finest loyalty. Many forms of conduct permissible in a workaday world for those acting at arm's length are forbidden to those bound by fiduciary ties. A trustee is held to something stricter that the morals of the market place."

From the outset Cardozo recognized that parties engaged in a joint venture are bound by fiduciary obligations in the same way as partners are bound, even though the joint venture agreement falls far short of a partnership agreement. While he considered that there was little to be gained "from a dissection of the precedents" and in fact saw no precedents to precisely fit the facts, he did find an "animating principle" in many of the decided cases. The cases he referred to concerned partners who had acted inequitably and Cardozo made it clear that there is no limit in equity to the types of transaction that attract undivided and unselfish loyalty. Once a fiduciary has acted in a way that promotes a selfish outcome at the expense of that relentless and supreme duty of loyalty a constructive trust is the remedial device through which "preference of self is made subordinate to loyalty to others".

\section{Joint Venturers and Partners}

Although Cardozo clearly differentiates between partners and parties to a joint venture he continues to refer to the principles of the laws relating to partnerships to support his conclusion that Meinhard was the beneficiary of a trust over the new lease and its opportunities. The dissenting judgment was based on the fact that there was no partnership, merely a joint venture for a limited object which would end at a fixed time. Without a partnership there could be no fiduciary relationship. The correlation that was felt to exist between joint venture and partnership prevailed across the decades and indeed was reiterated in the case of Auag Resources to which I previously referred.

In 1985, in United Dominions Corporation v Brian Pty Ltd (1985) 60 A.L.R. 741, the High Court of Australia considered a joint venture agreement as though it were some form of partnership agreement, although a very limited sort of partnership for one venture only. Gibbs CJ said there was, in the circumstances of the case, a "....relationship between UDC and Brian based on the same mutual trust and confidence, and requiring the same good faith and fairness, as if a formal partnership deed had been executed."

In the same way that Meinhard had been left out of the negotiations for the new lease in the first case, so too had Brian been kept in ignorance - this time about a clause in the mortgage agreement that would make Brian liable for debts 
under other mortgages that bore no relation to the project in which the company was engaged. The judgment delivered by Mason Brennan and Deane JJ referred in passing to the case of Meinhard $v$ Salmon. In agreeing that UDC had breached its fiduciary obligations to Brian, the judges come to the conclusion that the term "joint venture" is not a technical one that has a settled common law meaning and these judges consider that a joint venture may be undertaken in the form of a partnership but the term is also "apposite to refer to a joint undertaking or activity carried out through a medium other than a partnership." The judges were not prepared to accept Cardozo's proposition that the relationship between those in a joint venture is necessarily a fiduciary one. Instead they came to the conclusion that whether or not a relationship is a fiduciary one will depend on the form of the particular venture and the obligations which the parties have undertaken.

\subsection{Fiduciary Obligations}

This approach to fiduciary relationships was later seen in the dictum of Millet J (as he then was) in the case of Bristol \& West Building Society v Mothew (1998) Ch 1 when he said, "A fiduciary is someone who has undertaken to act for another in a particular matter in circumstances that give rise to a relationship of trust and confidence. The distinguishing obligation of a fiduciary is the obligation of loyalty."

It has often been said by judges and academics that one is not subject to fiduciary obligations because one is a fiduciary; it is because one is subject to them that one is a fiduciary.

In the case of Brian the relationship between the parties was one of prospective participants in a joint undertaking who had embarked upon the conduct of the venture before the precise terms of the agreement have been reached. In fact the court went on to say that the fiduciary nature of the parties in these circumstances may be easier to see than afterwards when the fine detail of their obligations towards each other have been expressly defined in a formal agreement. This is not, in my opinion, to suggest that once the formal agreement has been reached the fiduciary obligations cease to exist, but simply that the formal agreement may obfuscate the fiduciary relationship. If a fiduciary duty had been found to exist in these circumstances in New Zealand an institutional constructive trust would have been the appropriate means by which to protect the claimant's entitlement. The precise stage of the agreement in Brian was that the parties had all agreed to participate in the venture and each of them had agreed to make financial contributions to the cost of the project. The relationship was already based on mutual confidence.

In the case of Meinhard the test can be applied in the same way: the parties were already acting together in a joint venture. They were already participating in a joint venture and the proposed renewal of the existing lease should have been revealed to Meinhard to avoid a breach of fiduciary duty. The fact that this was a new venture with the new lease of the Bristol coming together with the lease of the new premises does not negate the relationship that continued to exist between the parties. Cardozo did not put his proposition into these terms but I believe this was the upshot of his general proposition that those in a joint venture are under fiduciary obligations. To paraphrase Finn's words, they are fiduciaries because they are under obligations of good faith and those obligations arose out of their relationship as participants in a joint venture.

\subsection{Good Faith and Fiduciary Obligations}

Turning now to a New Zealand case of 1991, Kiwi Gold No Liability v Prophecy Mining No Liability CA30/01, which was heard in the Court of Appeal on 1 July 1991, I would like to compare the approach to the fiduciary obligations arising out of joint ventures seen in this case with the previous judgments of Meinhard and Brian. In Kiwi Gold judgment was delivered by McKay $\mathrm{J}$ and, after reviewing the facts carefully, it was held that the relationship between the parties was not enough to establish fiduciary obligation but that the parties were under duties to act reasonably and in good faith but these duties were implied from the terms of the contract. Taking the first point, that there was no fiduciary obligation, it appeared from the facts that there was no formal joint venture agreement, although the terms for the proposed agreement had been clearly set out. One of the parties was working towards fulfilling the terms of the agreement by preparing a budget and work programme which were submitted to Kiwi Gold for approval. If we apply the reasoning in the case of Brian to these circumstances it would seem that there is evidence to support the existence of a fiduciary obligation. However the Court of Appeal decided that the judge at first instance had been wrong, that there was in fact no fiduciary relationship but there were duties of good faith and loyalty owed by each of the parties to the other which arose out of the contract itself. So in this instance a relationship that arose out of the contract, imposing duties of good faith and reasonably towards each other was insufficient to be termed a fiduciary relationship. However the Court of Appeal does not specify why the relationship that imposed the duty of good faith fell short of constituting a fiduciary relationship.

Dr. Finn tells us that when parties are under a duty of good faith between each other, a fiduciary relationship has come about. In fact it is only the existence of the duty of good faith that characterizes the fiduciary. McGechan, McKay and Casey JJ in Kiwi Gold clearly disagree, but in the judgment there is no discussion of when a fiduciary relationship may come into existence. The judge at first instance, Thomas $\mathrm{J}$, held that the fiduciary obligation arose as a result of the 
relationship of the joint venture partners. The position held by the High Court of Australia in Brian was that joint ventures did not necessarily give rise to fiduciary relationships but in that case the test applied was whether the parties had agreed to be a participant in the joint venture and had promised to contribute towards the cost of the project in which each had agreed to participate. It would seem that the facts of the Kiwi Gold case and Brian are very similar on this point. The Court of Appeal in Kiwi Gold did not refer to Brian or any decided cases on fiduciary relationships, preferring to rely on the contract to underpin the parties' duty towards each other. The appropriate remedy therefore would be damages based on the loss suffered by the plaintiff whereas a breach of fiduciary duty would have led to a disgorgement of a proportion of the profits made by the defendant.

\subsection{The Element of Vulnerability}

In 1995 the High Court in Auckland reviewed and applied the case of UDC v Brian when deciding the case of Dickie $v$ Torbay Pharmacy (1986) Ltd (1995) 3 NZLR 429. Brian was used to support the proposition that it is now established that a fiduciary relationship can exist in a co-ventureship "on the facts of the particular manner". In Brian it was said that the fiduciary nature of the relationship will depend upon the form which the joint venture takes and upon the obligations to which the parties have committed themselves. It was agreed in Dickie v Torbay that all the criteria which are routinely looked for in a fiduciary relationship were there: mutual trust, dependence and reliance. However Hammond J added another criterion when he referred to the "vulnerability of some parties (the doctors)" and the exercise of power by B. The elements of vulnerability and use of power over one party by another arises out of consideration of the case of LAC Minerals Ltd v International Corona Resources Ltd (1989) 61 DLR $\left(4^{\text {th }}\right) 14$.

While the use of power over vulnerable parties may be a suitable criterion for finding a fiduciary relationship to exist in some circumstances, I believe it is unnecessary and misleading to introduce this element in cases involving joint ventures. It is only necessary to show a mutual reliance in the joint venture, an intention to be bound by obligations to each other, for example the obligation to supply finance or expertise. There is no need to show any particular vulnerability by one party to another because by the mere fact that they are relying on each other in the joint venture makes each one vulnerable to the others. By including this new element the Court is leaving the case open to misinterpretation that vulnerability is a requirement for finding a fiduciary relationship, whereas in fact it is just one of a number of considerations that may lead to the finding of a fiduciary relationship - commitment to a joint venture is another. In fact, the court in Auag Resources stated that if there is no fiduciary duty imported by status such as partnership, then any fiduciary duty must usually be based on the vulnerability of the complaining party.

In the case of Arklow v MacLean the Court found that there was no breach of fiduciary duty because the parties had not entered into a relationship characterized by a mutual reliance upon each other which gave rise to a duty of loyalty. There was never any question of vulnerability of one party to another. It was very well summed up in the case of Hodgkinson $v$ Simms (1994) 117 DLR $\left(4^{\text {th }}\right) 161$ at page 176: “...the question to ask is whether, given all the surrounding circumstances, one party could reasonably have expected that the other party would act in the former's best interests with respect to the subject matter at issue. Discretion, influence, vulnerability and trust were mentioned as non-exhaustive examples of evidential factors to be considered when making this determination..."

In the light of the reasoning in Hodgkinson $v$ Simms it is clear that participants in a joint venture may be considered to be in a fiduciary relationship with each other, in the same way that partners are understood to be fiduciaries. Moreover, the finding of the fiduciary relationship does not arise because the participants in the joint ventures look a little like partners, albeit for a single venture only, but they are fiduciaries because the relationship between the parties enjoys the same degree of mutual trust and expectation of good faith as is present in a partnership.

\subsubsection{Misinterpretation of the law}

Returning to the reasoning in the case of Auag Resources Ltd, I suggested that some of the misinterpretation of the law in this area arose, in my opinion, out of the misplaced reliance on the finding of vulnerability on the part of one party and that it is only this vulnerability that attracts the protection of equity. This is simply not true. While equity may well impose a trust to restore property to the rightful beneficiary in cases where a position of trust has been abused, it is equally appropriate for equity to recognize fiduciary relationships between persons who have voluntarily undertaken obligations between themselves to act in good faith. The Court's role is to discover which commercial transactions do attract such undertakings of good faith and which do not. For example a simple sale and purchase agreement may be immune from a finding of a fiduciary obligation, as was found in Norbrook Laboratories $v$ Bomac Unreported High Court judgment in 2002(CP241-SW02), where the court declined to find fiduciary obligations to exist, saying that the issue of confidentiality was wholly governed by the contract. The court said that once parties have agreed the extent of any obligation of confidence then equity should not impose an obligation that was more stringent than that which had been agreed. However the court by no means ruled out the possibility of fiduciary obligations should the circumstances merit them. 


\section{Appropriate Remedy for Breach}

Once the fiduciary obligation has been found to exist and it has been established that a breach has occurred the court must then undertake to establish the remedy that would be appropriate. In some cases it has been said that it is appropriate to discover what has been lost by the claimant and find what has been described as a "pragmatic solution to the whole problem" (Dickie v Torbay Pharmacy (1986) (1995) 3 NZLR 429"). In some ways this approach reflects principles relating to equity's historical power to dissolve partnerships applying an inherent "restorative" power over contributions to the enterprise. In Baumgartner v Baumgartner (1987) 164 CLR 137 per Mason J at 148, Mason J referred to a "general equitable principle which restores to a party, contributions, which he or she has made to a joint endeavour which fails". However these principles may not provide an adequate solution when what is lost is not contributions but an opportunity to increase wealth. The question then arises as to the nature of this compensatory remedy - whether it is truly compensatory of whether damages are being imposed in a punitive way to represent a punishment for breach of fiduciary duties.

In Joseph Bailey $v$ Namol in 1994 the Federal Court of Australia said that there are authorities in Canada (such as Norberg $v$ Wynrib (1992) 92 DLR $\left(4^{\text {th }}\right) 440$ ) and in New Zealand which suggest, as a general proposition, that punitive damages may be awarded for breach of fiduciary duty. The authority for this proposition in New Zealand is Aquaculture Corporation v New Zealand Green Mussel Co Ltd (1990) 3NZLR 299 which has been described by Paul Finn (1998) as providing a "basket of remedies" where appropriateness is the arbiter of the remedy to be awarded. In the UK, Law Commission Report 247 recommended that the law should be changed to permit a judge to award punitive damages for any tort or equitable wrong. Examples from Canada and New Zealand were cited in support of this recommendation, despite the lack of English authorities for awarding exemplary or punitive damages for an equitable wrong.

In the more recent decision by the New Zealand Supreme Court in Chirnside v Fay(2006) NZSC 68 Tipping J delivered a judgment on behalf of himself and Blanchard $\mathrm{J}$. The separate judgment stems from their disagreement with Elias CJ on the point of allowances that were due to Mr. Chirnside. In other respects, however, the three judges were ad idem. Tipping $\mathrm{J}$ said that the remedy of damages for loss of chance preferred by the Court of Appeal was inappropriate in this case because it was inconsistent with the finding that the parties were joint venturers and already bound by fiduciary duties in a profitable scheme. He said "the case must be dealt with on the same basis as that which was adopted by the High Court. This basis represented equitable compensation or damages by analogy with disgorgement of profits." He explained that because there had been no sale of the property in question a valuation figure for the project had to be used as a substitute for the sale price. He was happy to speak in terms of equitable compensation or damages even when discussing the remedy for a breach of a duty imposed equity.

\subsection{The Award of Equitable Damages}

It was stated in the UK Law Commissioner's Report that the position in Australia was less clearly in favour of awarding damages in cases founded on equitable principles. The case of Harris v Digital Pulse Pty Ltd (2003) NSWCA 10, gives considerable insight into Australia's position on the matter. At first instance the judge reasoned that there was no authority which decides that exemplary damages cannot, as a matter or principle, be given by a court of equity for breach of fiduciary duty. However the majority in the Court of Appeal disagreed, Mason J dissenting. In his judgment Spigelman CJ considered a point that had been raised by the Court of Appeal in New Zealand In Chirnside $v$ Fay (2004) 3 NZLR 637 on the relationship between equitable compensatory relief and common law damages, where the two were said to be similar but different. Spigelman CJ says that the monetary award known as "damages" in common law cannot and should not be reflected in equity and he goes on to say, at paragraph 20, that the "integrity of equity...is not well served by adopting a common law remedy" that has been developed in a different context and on a different conceptual foundation. He refers to the fusion fallacy in Australia; the proposition that the joint administration of two distinct bodies of law means that the doctrines of one are applicable to the other. This can be compared to the approach taken by the New Zealand Court of Appeal in Chirnside, where it was said that the distinction between law and equity has effectively lost its force.

The Supreme Court of New Zealand in Chirnside did not make a final ruling on the applicability of damages in such cases because there was no need to do so. The parties were found to be in a joint venture relationship where one of them had breach his fiduciary duty to the other. However the property, as pointed out by Tipping J, had not been sold so the payment made to Mr. Fay was based on the value of the property, this being seen as analogous to the profit made by Mr. Chirnside. Payment was to be made to Mr. Fay amounting to half the calculated profit with some allowance deducted for Mr. Chirnside's additional work. It seems that Mr. Fay was to have his proprietary interest in the joint venture recognized but his proprietary interest was to be satisfied by a payment equivalent to his entitlement. Without being clear on this point it would appear that the Court imposed a constructive trust over the property based on the unjust enrichment of Mr. Chirnside. His action in excluding Mr. Fay from the project rendered his profit from the venture unjust. He was entitled to some extra profit because of his extra work and risk and in juridical terms this 
proportion of the profit was not unjustly retained. Monetary awards to satisfy constructive trusts are not uncommon.

\section{Constructive Trust based on Unjust Enrichment}

There is a line of New Zealand cases which supports the proposition that the proper basis for the constructive trust is unjust enrichment. This line of reasoning begins at Gillies $v$ Keogh (1989) 2 NZLR 327 . It was heard in the Court of Appeal and Cooke, sitting as President of the Court of Appeal, said, "This case is another stage in the evolution of the New Zealand law of constructive trusts and the like. It enables the court to add expressly one element of certainty in a field where it is sometimes said to be lacking and complaints of 'palm tree' justice are voiced".

The case itself dealt with relationship property held in the name of one party only in a de fact relationship at a time before the law was changed in NZ to give separating de facto partners in a relationship of more than three years duration the same rights over the disposition of property as married couples. Cooke P commented, "Normally makes no difference in the result whether one talks of constructive trust or unjust enrichment, imputed common intention or estoppel" and he referred to "the leadership of Dickson J" in Canada where, he says, the concept of unjust enrichment has continued to be developed. The Canadian case that he was referring to, Sorochan v Sorochan (1986) 29 DLR (4 ${ }^{\text {th }}$ ), was also one where the relationship assets were solely in the hands of the male partner and where there was enrichment, a corresponding detriment and an absence of juristic reason for the enrichment. Lord Denning, whose comments were quoted earlier in Nelson $v$ Larhol (above), was dealing with cheques, fraudulently drawn on a trust account, that were cashed by a third party to whom the fraudster owed gambling debts. It is not surprising that these 'hard' cases, where there was obviously potential for injustice if a proprietary remedy were not found, should give rise to a tendency for the judiciary to exercise flexibility if possible.

Cooke P saw no reason why the Canadian approach should not be adopted in New Zealand despite the fact that the law in Australia appeared to be settled on a contrary course. For example in Baumgartner v Baumgartner (1987) 164 CLR 137 the High Court of Australia looked for unconscionable conduct by the defendant rather than unjust enrichment, although one member of the court in that case (Toohey $\mathrm{J}$ ) accepted unjust enrichment as an alternative basis for the same point. By the time Gillies $v$ Keogh was heard the use of unjust enrichment as the basis for the finding of a remedial constructive trust in Canada had been accepted for about 9 or 10 years. It had been well established since Pettkus v Becker (1980) 117 DLR $\left(3^{\text {rd }}\right) 257$, where the court, per Dickson J, placed unjust enrichment at the heart of the constructive trust. Dickson J relied on the 1760 English case of Moses v Macferlan (1760) 2 Burr 1005, where it was said that "the defendant, upon the circumstances of the case, is obliged by the ties of natural justice and equity to refund the money". Dickson J went on to say that it would be both undesirable and impossible to define all the circumstances in which an unjust enrichment might arise. This has certainly proven to be true in New Zealand where the concept of unjust enrichment has been instrumental the success of demands for the return of money from a widening range of bodies. It has been said that the great advantage of ancient principles of equity is their flexibility so the judiciary can take advantage of their malleability to accommodate the changing needs and mores of society to achieve justice.

\subsection{Proprietary Interests}

The quest for justice may be seen as dangerous as it can lead to a loosening of the bonds linking equitable remedies with a proprietary interest that had existed before the behaviour that led to the unjust enrichment. An institutional constructive trust recognises the necessity of some previously existing fiduciary duty, that has been breached, or some proprietary rights that had been established before the actions that gave rise to the unjust enrichment. A remedial constructive trust, imposed in the name of justice, requires neither a subsisting proprietary interest nor any established fiduciary duty. Instead the remedial constructive trust is imposed where there is an enrichment, a corresponding detriment where there is no juridical reason for sustaining the enrichment. It was this sense of danger, of losing the structure of the traditionally accepted criteria underlying constructive trusts, that led the court in 1975 in Carly $v$ Farrelly (1975) NZLR 356 to declare adamantly that the remedial constructive trust based on unjust enrichment was not the law in NZ. In 1979 Mahon J set a long face against the proposition in Avondale Printers v Haggie (1979) 2 NZLR 124 so some intervening event must have led to the change in judicial attitudes between 1979 and $1989 . \quad$ In my opinion the answer lies in a case heard in 1990 by the NZ Court of Appeal.

Aquaculture Corp v NZ Green Mussel Co Ltd (1990) 3 NZLR 299 was decided by the Court of Appeal and in this case the court formulated the 'basket of remedies' approach. The aim was to make as full a range of remedies available as possible so that a remedy might be chosen because it is appropriate without having to consider whether its origin was in common law, equity or statute. This decision signalled the New Zealand Court of Appeal's willingness to focus on the outcome of a particular case rather than the theoretical foundations of the remedy so the remedy could be chosen on the basis that it provides the best outcome not because the antecedents of the remedy arose out of equity or the common law or even indeed from statute. Around that same time, in 1989, the Supreme Court of Canada heard LAC Minerals Ltd v International Corona Resources (1989) 61 DLR $\left(4^{\text {th }}\right)$ and invoked a constructive trust based on unjust enrichment.

When the courts in a particular jurisdiction move away from distinctions like relief in common law versus relief in 
equity they appear to be signalling a willingness to derive remedies from any source that achieves the desired outcome. So proprietary relief, by way of a constructive trust, can be awarded, without first finding the proprietary interest or breached fiduciary duty that would traditionally have been at the heart of the remedy. For example in Lankow $v$ Rose (1995) 1 NZLR 277, the institutional constructive trust was established through elements that the plaintiff had to prove. There had to be contributions made to the property claimed, either direct or indirect. There had to be an expectation on the part of the plaintiff that these contributions would give rise to an interest in the property and that expectation had to be a reasonable one. The defendant should also reasonably expect to yield to the claimant and give the interest. Sometimes this acquiescence on the part of the defendant to yield an interest to the claimant may be evidenced by a promise or some kind of agreement. So the proprietary interest in the property was vested in the claimant before the court became involved, through the contributions, reasonable expectation of an interest that the defendant would reasonably expect to yield. The court merely acknowledges that the institutional constructive trust exists.

\subsection{Remedial Constructive Trusts without Pre-existing Proprietary Interests}

The remedial constructive trust, on the other hand, is not based on any pre-existing proprietary interest. Instead it is based on the court's view of what is just and reasonable in the circumstances. So it is based on the broad equitable principles that are being developed under the banner of the law of restitution, those of unjust enrichment. Once we find unjust enrichment it is a short step to the imposition of the remedial constructive trust which can impose a proprietary remedy where no proprietary interest hitherto existed. In 1993 Hammond J in the NZ High Court case of Daly v Gilbert (1993) 3 NZLR 731 applied the reasoning from Gillies $v$ Keogh and said there is room for extension in terms of relief available and the issue is not the enrichment but whether it is unjust. Hammond $\mathrm{J}$ cited, as have many judges in this sort of case, the judgment of Lord Goff when he was sitting as Mr Justice Goff in the case of $B P$ Exploration (Libya) v Hunt (No 2) (1979) 1 WLR 783 where he said that the cause of action based in unjust enrichment has broad outlines. There must be receipt by the defendant of a benefit at the plaintiff's expense in such circumstances that it would be unjust to allow the defendant to retain the benefit.

Lord Goff, as he was in 1996, was part of the Privy Council panel which heard the case of Goss v Chilcott (1996) 3 NZLR 385 and it was he who delivered the judgment. It was a case concerning money paid for a consideration that had failed and he appeared to consider the question on the basis of a developing law founded on the principle of unjust enrichment. By the time National Bank of NZ v Waitaki International Processing (NI) Ltd (1999) 2NZLR 211 (CA), was heard three years later the Court of Appeal was expressing the issue in terms of unjust enrichment using Lord Goff's formula. Despite this, in the same year, (1999), Salmon J in the Court of Appeal case of Rod Milner v A-G (1999) 2 NZLR 568, stated that the principle of unjust enrichment did not yet have the status of a cause of action in itself and cited statements by Lord Browne-Wilkinson in Woolwich Equitable Building Society v Inland Revenue Commissioners (1993) AC 70, to support him when he said, "This is not the appropriate occasion to consider whether the time has come to give the principle such a status". He did not close the door on the idea, but simply postponed the recognition of unjust enrichment as a cause of action in its own right. So if it has not already been accepted as a cause of action it would appear that members of the court believe we are on the verge of doing so. It remains to consider what the factors would be that would tip the balance of acceptance.

\section{A Liberal Approach to the Distinctions between Equity and Common Law}

This brings me back to my proposition that if our judiciary is prepared to adopt a liberal approach to issues of distinction between equity and common law then it is a small step to extend that liberal approach and accept unjust enrichment as a cause of action giving rise to a constructive trust as the remedy. Whether the constructive trust imposed would be remedial or institutional would depend upon the circumstances of the case. For example it has been suggested that a fiduciary relationship is not a necessary requirement for a remedial constructive trust, in Commonwealth Reserves I v Chodar (2001) 2 NZLR 374 per Glazebrook J at paragraph 45. However the grant of proprietary relief without the basis of breach of fiduciary duty must be regarded with caution. The remedial constructive trust is imposed at the discretion of the court so while it is potentially available it is not inevitable that it will be awarded. There is another issue to be considered here. Situations where there has been unjust enrichment but where there is no fiduciary relationship are hard to envisage. Even in cases where the primary relationship between the parties is contractual the courts have had no difficulty in finding a fiduciary relationship did exist as a precursor to the imposition of a constructive trust. In that case an institutional constructive trust would arise automatically whenever a breach of fiduciary duty occurred, obviating the necessity of considering a remedial constructive trust.

\subsection{The Remedial Constructive Trust}

In Fortex Group Ltd v MacIntosh (1998) 3 NZLR 171 CA the plaintiff employees sought a declaration of trust over the assets of the company on the basis that Fortex was under an obligation to place money retained from their wages into a superannuation fund. Not only had the company unilaterally elected to pay the money into the fund annually instead of monthly, it had ceased paying the employees' contributions into the fund altogether. The issue in the case was, in part, whether there was any identifiable property over which the trust could be imposed. The obstacle to identifying 
money that should have been allocated to the fund was the fact that the company's bank account was at all material times overdrawn. By retaining the employees' money Fortex had sought not to increase the amount by which it was overdrawn. There were assets of the company available to satisfy some of the claims of the secured debenture holders and it was decided in the Court of Appeal (overturning the judge at first instance) that it would be unjust to allow the employees to succeed in their claim as the money would be taken from the debenture holders who had not received it without juridical reason. Blanchard $\mathrm{J}$ went so far as to say that, although the company was the sole trustee of the superannuation fund this did not mean it had the duties of a trustee nor did it owe any fiduciary duty in relation to its contractual obligation to pay the employees' pension contributions from its general bank account to a separate account for that purpose. Tipping $\mathrm{J}$ was determined to avoid the creation of backdated proprietary interests.

The Court regarded the dispute as between the employees and the debenture holders, saying it would be unconscionable for the employees to gain at the expense of the debenture holders as the latter were secured creditors, whereas the employees were merely unsecured creditors. However there seem to be some issues that were not addressed by the Court of Appeal. The employees were vulnerable in their position with the employers. They trusted the employers to pay the retained money into the proper account promptly, as per the superannuation trust agreement. They were unable to compel the employers or to check that they had performed their duties. This is evidence of the vulnerable position of the employees. At the time of the initial failure by Fortex to pay promptly the retained money into the proper account it could be argued that a constructive trust arose based on the relative positions of the parties and the trust and confidence that one party placed in the other, in the manner of the parties in Sullivan v Management Agency (1985) 1 QB 428. This would have imposed fiduciary duties on Fortex to use the employees' money in accordance with the agreement or else cease to deduct the contributions. The fiduciary duty would have been breached at an earlier time than the one examined by the Court. The imposition of a remedial constructive trust at the earlier time would have obviated the necessity to find an identifiable pool of money since this type of trust looks only for an unjust enrichment. Fortex were unjustly enriched at the expense of the employees when it continued to deduct money from employees' salaries with no intention of paying those deductions into the fund. That enrichment could have been redressed by the imposition of a remedial constructive trust over the assets of the company and, once that earlier claim had been settled, the claims of the debenture holders could have been addressed. It is unfortunate when two groups of innocent people, investors and employees, have to suffer loss but in this case the interests of the employees were sacrificed to the interests of investors.

\subsection{Lack of Fiduciary Relationship no bar to Remedial Constructive Trust}

Glazebrook J, in Commonwealth Reserves I v Chodar (2001) 2 NZLR 374 found that she had jurisdiction to award a remedial constructive trust and that there appeared to be a clear case of unjust enrichment. She said that the remedial constructive trust should only be imposed where other available remedies are inadequate and that she considered lack of a fiduciary relationship not to be an impediment to the imposition of such a trust. In choosing to exercise her discretion and impose the constructive trust Glazebrook J looked carefully at the conduct of the defendant and at the interests of third parties. As the plaintiffs had not retained equitable title in the money paid to the defendant, and as there was no fiduciary relationship between the parties, the only available remedy was the remedial constructive trust, which was duly imposed.

As Cooke P said in Gillies $v$ Keogh, "Normally it makes no practical difference in the result whether one talks of constructive trust, unjust enrichment, imputed common intention or estoppel." It is certainly true that in reading the cases in this area there is a sense that the 'basket of remedies' approach advocated in Aquaculture is truly in use and constructive trusts and unjust enrichment are used in many different ways. In Smith v Hugh Watt Society (2004) 1 NZLR 537 the court decided that the transferee of real property had knowingly received property in breach of trust. In that case, the recipient of the property acquired notice of the existence of the trust after the transfer of the property through its solicitor and agent. The constructive trust was imposed based on unjust enrichment. Thomas J said, in Powell v Thompson (1991) 1 NZLR 597, at 609, "the property which is acquired is 'encumbered' by an equitable interest." In Smith v Hugh Watt the society was found to have been unjustly enriched at the expense of those people who raised the original funds for the purchase of the property in question. A constructive trust was imposed over the property to protect the plaintiff's equitable interest.

\section{Quantum Meruit gives way to Unjust Enrichment}

However, prior to that case Buysers v Dean (2002) NZFLR 1 was heard where there was no application made for a proprietary remedy since the plaintiff had not made a contribution to the defendant's property and she did not have an expectation of a share in his property. Her claim was advanced by way of quantum meruit and unjust enrichment for money restitution for housekeeping and childcare over a nine year period which terminated prior to the commencement of the Property (Relationships) Act 1976. There was no identifiable property to which the plaintiff could lay claim. Hers was a simple claim that either the defendant had been unjustly enriched by her because she had not worked during their relationship but for seven years and nine weeks she had looked after their two children full time, or that she should 
get fair compensation for the benefit she provided. Despite the fact that there was no contractual relationship upon which to establish quantum meruit, the court followed the Australian precedent of Pavey v Mathews Pty v Paul (1986) 162 CLR 221 in allowing the claim to succeed. However to establish the quantum meruit claim in the absence of an implied contract it is necessary to establish that an incontrovertible benefit has been received by the defendant, the test for which is to show that "no reasonable man would say that the defendant was not enriched." (Peter Birks 1989). This kind of reasoning works well in cases such as the one cited, where a householder called the fire brigade believing the service was free but was wrong, because the cost of the service is readily established: Upton-on Severn Rural District Council v Powell (1942) 1 All ER 220.

In the present case of Buysers $v$ Dean the plaintiff tried to establish the true value of her services by calling witnesses who deal in household and child care provision and the total came to $\$ 201,420$. However the judge did not award that amount but instead considered it "entirely appropriate for the plaintiff to stay at home and care for the two infant children" but that "some compensation is justified for domestic housekeeping". Furthermore he considered that "the child care services were as much for the benefit of the plaintiff, as mother of the children". So the judgment moves from a claim in straightforward quantum meruit, compensation for a benefit received by the male partner, to a calculation based in part on the appropriateness of the plaintiff being responsible for child care. The compensation was further reduced to $\$ 58,000$ to take into account weekends and times when the father was at home to share in the responsibility. Whether or not this was adequate for services provided over a nine-year relationship I am not sure, but it would seem that the judge is leaning towards an unjust enrichment basis for his decision rather than quantum meruit. In unjust enrichment it is entirely acceptable for the calculation to be based on matters beyond the mathematics of a claim when looking for the factor that makes it unjust for a defendant to retain the benefit without compensating the plaintiff. I believe in this case it was the judge's reluctance to apply unjust enrichment principles to the issue for fear of opening the door to a proprietary claim where he believed none was justified.

\subsection{Indirect Contributions as Basis for Unjust Enrichment Claim}

In the same year, 2002, the Court of Appeal took a different approach in King $v$ Church (2002) NZFLR 555 where Tipping J's judgment in Lankow v Rose (1995) 1 NZLR 277 was applied allowing indirect contributions were allowed to qualify as contribution to the property. Tipping J said, "There may be greater difficulties of proof and assessment when the contributions are indirect, but, once established, they are as real as direct contributions." He went on to say that he would accept a service by the claimant as a contribution if its provisions helped the other party to acquire, improve or maintain the property or its value. Contributions under this test do not have to be financial, so contributions in the home may qualify on this basis as contributions to the home. Even where there is no proprietary interest in property available to the claimant there is no reason why the claim may not be satisfied by a monetary award. The basis of this analysis is the enrichment of the defendant at the expense of the claimant where it would be unjust for the defendant to retain the benefit without some award to the claimant. If we applied that reasoning to the previous case of Buysers $v$ Dean the claim would have been based on the claimant's contribution by child care and housework which enabled the defendant to increase the value of his assets unencumbered by the expense of providing care for his children and housekeeping. This was the approach adopted in Shears $v$ Waters (2002) NZFLR 673 where the court used its equitable jurisdiction to interfere with the assertion of strict legal rights on the basis that for the defendant to retain the full benefit would be unconscionable. In other words it would be an unjust enrichment that the defendant was not entitled to retain. In 2004 Ewing $v$ Donaldson, (CA231/03), was decided in the Court of Appeal of New Zealand on the basis that indirect contributions to the household including caring for the children in the absence of the male partner while he was on assignment with the RNZAF gave rise to an interest in property which was held by Mr Ewing alone. In this case Ms Donaldson was also awarded a share in assets that had been acquired using pension funds that had accrued to Mr Ewing during his time in the Air Force. A constructive trust was imposed to give effect to her claim. It was said that to pay her equivalent wages for the services she performed over the 20 year relationship was not enough. If this judgment were based on an institutional constructive trust then the evidence of a promise by Mr Ewing that he "would do good by" Ms Donaldson and that she should not "worry about anything, he would see it all through" would need to be relied on to support a legitimate expectation of a proprietary interest in the assets. It would seem to be more likely that the circumstances gave rise to a remedial constructive trust base on unjust enrichment where it would be inequitable for Mr Ewing to refute the contribution made by Ms Donaldson in the acquisition of the assets.

\section{Conclusion}

Flexibility has always been prized by Equity but the note of caution is often sounded that too much flexibility leads to uncertainty and too much discretion is judicial anarchy. However, if a wrong is identified where no remedy as yet would give relief it seems that it is the very essence of equity that all available sources should be used to find a remedy. In New Zealand the blurring of the differences between common law relationships and fiduciary duties has been the subject of much debate in which the blending of the two is usually referred to as fusion. Commentators who argue against the possibility of fusion between common law and equity refer to 'the fusion fallacy' saying that there was 
nothing in the Judicature Act to show it was intended to codify law and equity into one subject matter. While the roots of the conceptual distinction between law and equity remain intact, in many courts the practical ramifications of that distinction are being eroded, particularly in commercial cases. It is sometimes felt necessary to impart some sense of morality into cases involving businessmen or sometimes the reason is pragmatic, simply to find the most suitable remedy for the situation.

\section{References}

Birks, P. (1989). An Introduction to the Law of Restitution Oxford: OUP p.116.

Finn, P. (1998). Equitable Doctrine and Discretion in Remedies. In W.R. Cornish, P. Nolan, J. O’Sullivan, and G. Virgo (Eds.), Restitution, Past, Present \& Future. Oxford: Hart Publishing. 